\title{
The Influence of Learning Models on Scientific Literacy in Physics Course: A Meta-Analysis Research
}

\author{
Yunika Apriyani ${ }^{1}$, Yetti Supriyati ${ }^{2}$, Gaguk Margono ${ }^{3}$ \\ 1,2,3State University of Jakarta, Indonesia \\ Email: yunikaapriyani27@gmail.com
}

\begin{abstract}
This study aims to analyze the influence of learning models on students' scientific literacy skills. This research method is a meta-analysis with a sample of ten national and international journal articles. The results of this study indicate that the STEAM learning model, STEM, Problem Based Learning, Literacy Learning Model, E-learning, Project Based Learning or combination models have an influence on students' scientific literacy skills because they connect classroom learning activities with students' daily lives and motivate students to participate actively in the learning process.
\end{abstract}

Keywords: Meta Analysis, Learning models, Scientific Literacy.

\section{A. INTRODUCTION}

Education aims to create high quality of human resources. Good human resources will support the quality of a country. As stated in the Indonesian regulation or Law number 20 of 2003 concerning the National Education System, the function of education is to develop a good national character and civilization (Bunyamin, 2016). Jacob Mahlangu proposes that education is the only way ahead for human survival in the future (Mahlangu, 2020). Future education is still a part of 21st century education. The 21st century is the age of knowledge, when information and technology evolve. One of the most prominent things in the 21st century is the increasingly connected world of science, resulting in faster synergies. 21st century learning demands on scientific literacy skills.

Scientific literacy is one of the skills needed in the 21st century among the 16 skills identified by the World Economic Forum (Lederman et al., 2013). Scientific literacy views the importance of thinking and acting skills that involve mastering thinking and use scientific thinking in recognizing and dealing with social problems (Rusilowati et al., 2016). Scientific literacy is important for students in understanding the environment, health, economy, modern social, and technology (Liu, 2009). Therefore, measuring scientific literacy is important in determining the level of scientific literacy of students in order to achieve high or good scientific literacy so that the quality of education can increase and be able to compete with other countries (Gultepe \& Kilic, 2015).

Scientific literacy is seen as a competency needed to improve the ability to think dynamically about science in relation to personal, social, political, economic, and other problems (Trilling, 2009). Scientific literacy can be developed through 
science education. Educational science related to the ability in using scientific knowledge and skills creatively based on sufficient evidence of everyday life in solving real problems based on understandable reasoning and based on scientific phenomena (Duffy, 2016 \& Ajayi, 2018). Science is not only the accumulations of visible evidences, but also observations that require interpretations and conclusions (Nurul, 2020).

In the midst of the intense challenges faced by society, a paradigm alteration is needed in the world of education systems that can provide a set of 21st century skills needed by students to face every aspect of global life. From various studies on the concepts and characteristics of 21st century education, it is undeniable that both are a great demand and challenge for teachers in teaching and learning activities (Trilling, 2009). Teachers like it or not, agree or disagree must balance the 21st century demands (Ministry, 2013). The teacher's role is very important in choosing the learning model used to improve students' scientific literacy skills. The learning model used in schools must be connected between the theories and applications they find in everyday life, so misconceptions will never exist (Sujarwo, 2008).

Model-Based Learning as the construction of mental models of phenomena (Gobert \& Buckley, 2000). Trianto, in the concept of the learning model states that the learning model is a plan or pattern used as a guide in planning classroom learning or tutorial learning. The learning model refers to the learning approach that will be used, including teaching objectives, stages in teaching and learning activities, learning environment, and classroom management (Siarova et al., 2019). The learning model used must be corresponding with the learning activities and objectives to be achieved (Jufri, 2013). Many learning models are applied by teachers in schools in order to lead students achieve the learning objectives. Each learning model puts emphasis on certain aspects compared to other learning models. In learning physics students must emphasize the basic concepts so that they do not memorize formulas, and calculate numbers only (Sahronih et al., 2019).

\section{B. METHOD}

This study uses a meta-analysis method by reviewing ten journals to determine how the influence of learning models on students' scientific literacy. The meta-analysis method involves a review of the diverse literature as well as reinterpreted conclusions from research in a particular field (Balemen $N$ and Nasional K P, 2018). This study focuses on several previous journals using the meta-analysis method. According to De Coster (2009), there are several steps in conducting meta-analysis research including ensuring and pursuing research topics to be summarized, finding and collecting research on predetermined topics and selecting them, calculating effect size, recognizing whether there is heterogeneity in effect size, and draw conclusions and interpret the results (Nurcahyani et al., 2021). 


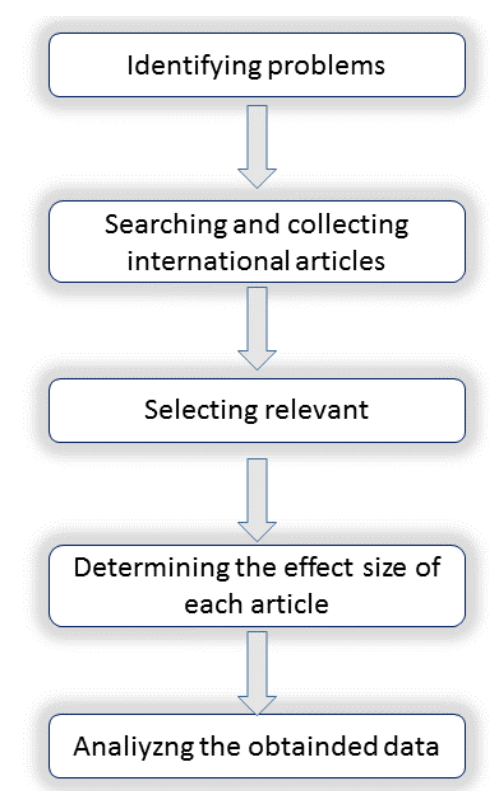

Figure 1 Research Procedure

To find a detailed description of the effect of several research models on scientific literacy in physics subjects, the analysis focuses on the results of research using experimental designs. This study focuses on meta-analysis by examining several research findings on learning models used in determining scientific literacy skills and exploring their influence in various forms of disciplines.

Data tabulation steps are (1) identification of research variables. Which after being found, is entered in the appropriate variable column, (2) identification of the mean and standard deviation of the experimental group and control group data for each subject/sub-study, (3) calculating effect size using the Glass formula (Glass, 1981) based on the mean and standard deviation, by finding the effect size $(\Delta)$ by dividing the difference in the experimental group mean $(\mathrm{XE})$ with the control group mean $(\mathrm{XK})$, with the control group standard deviation (Sk)(Nurcahyani et al., 2021). The formula is:

$$
\Delta=\frac{X E-X K}{S K}
$$

with effect size criteria (Glass, 1981) as follows:

1. effect size $\leq 0,15$ negligible effect

2. $0,15<$ effect size $\leq 0,40$ small effect

3. $0,40<$ effect size $\leq 0,75$ medium effect

4. $0,75<$ effect size $\leq 1.10$ high effect

5. $1.10<$ effect size $\leq 1,45$ very high effect

6. $1,45<$ effect size high influence

\section{RESULT AND DISCUSSION}

The number of articles obtained related to this research in general are 139 articles. The data is analyzed and selected in detail to find aspects related to learning models and physics subject. Finally, ten related articles are found for this research. The results obtained are analyzed comprehensively about the integration of physics and 
science studies and how learning models are applied to determine students' scientific literacy skills.

Table 1. List of Studies, Coding, and Effect Size4. Conclusion

\begin{tabular}{|c|c|c|c|c|c|c|}
\hline Researchers & Country & $\begin{array}{c}\text { Models } \\
\text { learning }\end{array}$ & Levels & Material & $\begin{array}{c}\text { Total } \\
\text { Respondents }\end{array}$ & $\begin{array}{c}\text { Size } \\
\text { Effect }\end{array}$ \\
\hline $\begin{array}{l}\text { Anderias } \\
\text { Henukh et } \\
\text { al. }(2021)\end{array}$ & Indonesia & $\begin{array}{l}\text { learning with } \\
\text { the STEM } \\
\text { approach based } \\
\text { on local } \\
\text { wisdom }\end{array}$ & $\begin{array}{l}\text { Junior High } \\
\text { School }\end{array}$ & heat & NA & 0.90 \\
\hline $\begin{array}{l}\text { Parno et al. } \\
\quad(2021)\end{array}$ & Indonesia & $\begin{array}{c}\text { STEM-based } \\
\text { guided inquiry } \\
\text { learning }\end{array}$ & $\begin{array}{l}\text { Senior High } \\
\text { School }\end{array}$ & fluid statics & 90 & 0.89 \\
\hline $\begin{array}{c}\text { Rina } \\
\text { Widiana et } \\
\text { al. (2020) }\end{array}$ & Indonesia & $\begin{array}{l}\text { Problem Based } \\
\text { Learning }\end{array}$ & $\begin{array}{l}\text { Senior High } \\
\text { School }\end{array}$ & NA & NA & 1.06 \\
\hline $\begin{array}{l}\text { Adriyawati, } \\
\text { et al. (2020) }\end{array}$ & Indonesia & $\begin{array}{c}\text { STEAM- } \\
\text { Project-Based } \\
\text { Learning } \\
\end{array}$ & $\begin{array}{c}\text { Elementary } \\
\text { School }\end{array}$ & $\begin{array}{l}\text { Alternative } \\
\text { Energy }\end{array}$ & 30 & 1.49 \\
\hline $\begin{array}{l}\text { Sri Astutik, } \\
\text { et al. (2019) }\end{array}$ & Indonesia & $\begin{array}{l}\text { Collaborative } \\
\text { Creativity (Cc) }\end{array}$ & $\begin{array}{l}\text { Senior High } \\
\text { School }\end{array}$ & $\begin{array}{l}\text { Straight } \\
\text { Motion }\end{array}$ & NA & 0.58 \\
\hline $\begin{array}{l}\text { Poedjiastoeti, } \\
\text { et al. (2018) }\end{array}$ & Indonesia & $\begin{array}{c}\text { Guided } \\
\text { Inquiry-based } \\
\text { Learning } \\
\end{array}$ & $\begin{array}{l}\text { Senior High } \\
\text { School }\end{array}$ & $\begin{array}{c}\text { solubility } \\
\text { and } \\
\text { solubility }\end{array}$ & 93 & 0.70 \\
\hline $\begin{array}{c}\text { Moh. } \\
\text { Budiyanto, } \\
\text { et al. (2018) } \\
\end{array}$ & Indonesia & E-learning & University & $\begin{array}{c}\text { Temperatur } \\
\text { and Heat }\end{array}$ & NA & 0.67 \\
\hline $\begin{array}{c}\text { T Sunarti } \\
\text { (2018) }\end{array}$ & Indonesia & $\begin{array}{c}\text { Literacy } \\
\text { Learning } \\
\text { Model (LLM) }\end{array}$ & University & NA & 120 & 0.62 \\
\hline $\begin{array}{l}\text { L Yuliati et } \\
\text { al. (2018) }\end{array}$ & Indonesia & $\begin{array}{c}\text { Inquiry-Based } \\
\text { Learning }\end{array}$ & $\begin{array}{c}\text { Senior High } \\
\text { School }\end{array}$ & NA & NA & 0.81 \\
\hline $\begin{array}{c}\text { Hendri } \\
\text { Saputra et al. } \\
(2017)\end{array}$ & Indonesia & $\begin{array}{c}\text { Inquiry Based } \\
\text { Learning on } \\
\text { Virtual } \\
\text { Laboratory } \\
\end{array}$ & University & $\begin{array}{l}\text { Dynamic } \\
\text { Electricity }\end{array}$ & 22 & 0.85 \\
\hline
\end{tabular}

Table 1 shows the data sought including researcher identity, country, material, subject, education level, number of respondents, and effect size. The average effect size is 0.857 , which means that the learning models used have a high influence on students' scientific literacy skills. In this study, eight models were used, they are STEM, Problem-Based Learning, Project-Based Learning, Inquiry-Based Learning, Literacy Learning Model (LLM), E-learning, Guided Inquiry-Based Learning and Collaborative Creativity (Cc). The highest influence on students' scientific literacy skills is the STEAM-Project-Based Learning model with an effect size of 1.49.

STEAM Project Based Learning model shows that the STEAM approach can develop high-level thinking skills, collaborations, argumentations, and creativities in participating students (Adriyawati et al., 2020).(Afriana et al., 2016) revealed that 
STEM Project-Based Learning (Integrated PBL) can increase students' interest in learning, develop scientific literacy skills, and provide students with opportunities to solve real-life problems and support future careers. The results of the study meet the indicators of one scientific literacy aspect proposed by (Shwartz et al., 2006), it is a high level of learning ability. The material used is Alternative Energy. In addition, the learning model with the STEM approach based on local wisdom obtained an effect size of 0.90 and STEM-based guided inquiry learning of 0.89. In STEM approach, students are challenged with contextual problems of everyday life then students are asked to recognize scientific concepts and also to verify application technology related to the problem (Parno et al., 2020). This process is an important part of STEM approaches because it can help students hone their understanding of the discussed topics, and this can trigger STEM professional activity and eliminate crossdisciplinary boundaries in the STEM field of work (Yuliati et al., 2018). Therefore, both STEM and STEAM approaches can be applied in teaching and learning activities to improve students' scientific literacy skills.

The second highest influence is Problem Based Learning with an effect size value of 1.06. The high scientific literacy skill is due to the model applied to stimulate active and critical students in getting solutions to problems (Briana \& Turnip, 2016). PBL model requires students to read in finding solutions, so that students are unwittingly trained in solving problems which then indirectly shape scientific literacy skills. Learning with PBL model helps students become independent learners. Problem Based Learning is a learning model that focuses on problems and questions so it is able to make students solve problems using concepts and principles that are appropriate and not far from scientific literacy that helps students in solving problems (Briana \& Turnip, 2016). Measurement of students' scientific literacy skills using models needs to be supported by literacy-based tests. In accordance with the research that has been conducted (Giriyanti, 2017) "the process of the problem-based model stages that students go through can bring the indicators used in students' scientific literacy fulfilled. The stages of the learning process from the problem-based model used can improve students' scientific literacy skills, one of them is in the aspect of competence".

Based on table 1 the model of Guided Inquiry-Based Learning, Inquiry-Based Learning and Inquiry Based Learning on Virtual Laboratory, successively, obtained effect sizes of $0.70,0.81$ and 0.85 . Broadly speaking, Inquiry-based Learning is learning that is able to place students as scientists, because students are directed to find scientific conceptions through laboratory experiment activities. Apart from that, in inquiry learning students are also invited to think logically, critically, and analytically, and build productive attitudes (Faradilla et al., 2018). Inquiry-Based Learning provides opportunities for students to be actively involved in the process of scientific inquiry and provides opportunities to practice their critical thinking skills in solving scientific problems (Sutiani et al., 2021). Inquiry learning also requires a laboratory, because laboratory activities aim to invite students to play an active role in exploring 
their own concepts, so that the information absorbed will be more meaningful and able to be implemented in everyday life (Saputra et al., 2017).

In the Collaborative Creativity (CC), E-learning and Literacy Learning Model (LLM), successively obtained the effect sizes of $0.58,0.67$ and 0.62 . Based on the three categories, they have a medium effect on scientific literacy skills. It shows that the three models can still be used to improve students' scientific literacy skills. The Collaborative Creativity (CC) model contains a creative idea of exploration steps. On this step students issue their ideas to formulate problems and hypotheses during the practicum so that it can improve the way students explore scientific questions (Astutik et al., 2019). Likewise, with E-learning, because in E-learning all information can be contained, so each individual must have the ability to filter and be critical of the existing information. According to Piaget's constructivism paradigm, one of the important skills possessed by students is the ability to regulate and control their thinking processes, including critical thinking skills, it is individual skills in using thinking strategies in analyzing arguments and providing interpretations based on correct and rational perceptions, analytical assumptions, and bias of logical arguments and interpretations. This pattern of thinking is included in higher-order thinking patterns and scientific literacy skills (Budiyanto et al., 2019). Therefore, the Collaborative Creativity (CC), E-learning, and Literacy Learning Model (LLM) can be applied in learning activities to improve students' scientific literacy skills.

\section{CONCLUSION}

Based on the discussion, it can be summed up that the STEAM, STEM, Problem Based Learning, Literacy Learning Model, E-learning, Project Based Learning or combination learning models have an influence on students' scientific literacy skills because they connect classroom learning activities with students' daily lives and motivate students to actively participate in the learning process. The implementation of the learning model used in learning activities depends on the student's environment. Therefore, the teacher must adapt to the condition of each students' environment.

\section{REFERENCE}

1. Adriyawati, Utomo, E., Rahmawati, Y., \& Mardiah, A. (2020). Steam-project-based learning integration to improve elementary school students' scientific literacy on alternative energy learning. Universal Journal of Educational Research, 8(5), 18631873. https://doi.org/10.13189/ujer.2020.080523

2. Afriana, J., Permanasari, A., \& Fitriani, A. (2016). Penerapan project based learning terintegrasi STEM untuk meningkatkan literasi sains siswa ditinjau dari gender. Jurnal Inovasi Pendidikan IPA, 2(2), 202. https://doi.org/10.21831/jipi.v2i2.8561

3. Astutik, S., Lesmono, A. D., \& Adani, D. A. L. (2019). Pengaruh Model Collaborative Creativity (Cc) Terhadap Kemampuan Literasi Sains Dan Hasil Belajar Fisika Siswa Di Sma. Saintifika, 21(1), 9-22. 
4. Balemen N and Nasional K P. (2018). Efektifitas Pembelajaran Berbasis Proyek Pada Pendidikan Ilmu Pengetahuan: Penelusuran Meta Analisis 5. 1-18.

5. Briana, J., \& Turnip, B. M. (2016). Pengaruh Model Problem Based Learning Terhadap Kemampuan Pemecahan Masalah Siswa Sma. INPAFI (Inovasi Pembelajaran Fisika), 4(3), 87-94. https://doi.org/10.24114/inpafi.v4i3.5597

6. Budiyanto, M., Sudibyo, E., \& Qosyim, A. (2019). Pembelajaran Fisika Dasar Menggunakan E-Learning Untuk Meningkatkan Literasi Sains Mahasiswa. Jurnal Penelitian Pendidikan IPA, 3(2), 82. https://doi.org/10.26740/jppipa.v3n2.p82-86

7. Bunyamin. (2016). Teacher Professionalism: A Study on Teacher's Professional And Pedagogic Competence at Vocational High Schools in the Northern Coastal $\begin{array}{llll}\text { of Jakarta. PPS UNJ, 118-131. } & \text { 9(2), }\end{array}$ https://www.infodesign.org.br/infodesign/article/view/355\%0Ahttp://www.aberg o.org.br/revista/index.php/ae/article/view/731\%0Ahttp://www.abergo.org.br/revi sta/index.php/ae/article/view/269\%0Ahttp://www.abergo.org.br/revista/index.ph $\mathrm{p} / \mathrm{ae} / \mathrm{article} / \mathrm{view} / 106$

8. Duffy, N. (2016). Literacy, Scientific Literacy and the Learning Needs of ESL Students Author: Natalie A 2011. https://doi.org/10.13140/RG.2.2.33252.58242

9. Faradilla, M., Hasan, M., \& Sulastri. (2018). The effectiveness of guided inquirybased student worksheets on students' generic science skills. Journal of Physics: Conference Series, 1088. https://doi.org/10.1088/1742-6596/1088/1/012106

10. Giriyanti, P. (2017). Pengaruh Model Pembelajaran Berbasis Masalah Terhadap Kemampuan Literasi Sains Siswa Pada Materi Ekosistem Kelas X SMA. Skripsi Pendidikan Biologi, 05, 1-8.

11. Gobert, J. D., \& Buckley, C. (2000). Introduction to model-based teaching and learning in science education. International Journal of Science Education, 22(9), 891894. https://doi.org/10.1080/095006900416839

12. Gultepe, N., \& Kilic, Z. (2015). Effect of scientific argumentation on the development of scientific process skills in the context of teaching chemistry. International Journal of Environmental and Science Education, 10(1), 111-132. https://doi.org/10.12973/ijese.2015.234a

13. Jufri, W. (2013). Belajar dan pembelajaran sains. Reka Cipta.

14. Lederman, N. G., Lederman, J. S., \& Antink, A. (2013). Nature of Science and Scientific Inquiry as Contexts for the Learning of Science and Achievement of Scientific Literacy. International Journal of Education in Mathematics, Science and Technology, 1(3), 138-147. www.ijemst.com

15. Liu, X. (2009). Beyond science literacy: Science and the public. International Journal of Environmental and Science Education, 4(3), 301-311.

16. Mahlangu, J. (2020). The importance of education for the survival of humanity. January 2019, 1-25.

17. Ministry. (2013). 21 st Century Teaching and Learning What We Heard at the 2013 Round Table .... 2013-2014. 
18. Nurcahyani, D., Yuberti, Irwandani, Rahmayanti, H., Ichsan, I. Z., \& Rahman, M. (2021). Ethnoscience learning on science literacy of physics material to support environment: A meta-analysis research. Journal of Physics: Conference Series, 1796(1), 0-8. https://doi.org/10.1088/1742-6596/1796/1/012094

19. Nurul, mas'ud waqiah. (2020). Analysis of Interest and Scientific Literacy Skills of Senior High School in Learning Physics. Jurnal Kependidikan Fisika, 53(9), 1689_ 1699.

20. Parno, Yuliati, L., Munfaridah, N., Ali, M., Indrasari, N., \& Rosyidah, F. U. N. (2020). The impact of STEM-based guided inquiry learning on students' scientific literacy in the topic of fluid statics. Journal of Physics: Conference Series, 1481(1). https://doi.org/10.1088/1742-6596/1481/1/012104

21. Rusilowati, A., Kurniawati, L., Nugroho, S. E., \& Widiyatmoko, A. (2016). Developing an instrument of scientific literacy asessment on the cycle theme. International Journal of Environmental and Science Education, 11(12), 5718-5727.

22. Sahronih, S., Purwanto, A., \& Sumantri, M. S. (2019). The effect of interactive learning media on students' science learning outcomes. ACM International Conference Proceeding Series, Part 20-24. https://doi.org/10.1145/3323771.3323797

23. Saputra, H., Al Auwal, T. M. R., \& Mustika, D. (2017). Pembelajaran Inkuiri Berbasis Virtual Laboratory Untuk Meningkatkan Kemampuan Literasi Sains Mahasiswa Calon Guru Pendidikan Fisika Universitas Samudra. Jurnal IPA E Pembelajaran IPA, 1(2), 143-148. https://doi.org/10.24815/jipi.v1i2.9688

24. Shwartz, Y., Ben-Zvi, R., \& Hofstein, A. (2006). The use of scientific literacy taxonomy for assessing the development of chemical literacy among high-school students. Chemistry Education Research and Practice, 7(4), 203-225. https://doi.org/10.1039/B6RP90011A

25. Siarova, H., Sternadel, D., \& Szőnyi, E. (2019). Research for CULT Committee - Science and Scientific Literacy as an Educational Challenge (Issue March, pp. 1-64). https://www.europarl.europa.eu/RegData/etudes/STUD/2019/629188/IPOL_STU( 2019)629188_EN.pdf

26. Sujarwo. (2008). Desain sistem pembelajaran. Universitas Negeri Yogyakarta, 2008, 1-18.

http://staffnew.uny.ac.id/upload/132304795/penelitian/Desain+Pembelajaranpekerti.pdf

27. Sutiani, A., Situmorang, M., \& Silalahi, A. (2021). Implementation of an Inquiry Learning Model with Science Literacy to Improve Student Critical Thinking Skills. International Journal of Instruction, 14(2), 117-138. https://doi.org/10.29333/iji.2021.1428a

28. Trilling, B. \& F. (2009). 21st Century skills: learning for life in our times. Jossey-Basse. 29. Yuliati, L., Parno, P., Hapsari, A. A., Nurhidayah, F., \& Halim, L. (2018). Building Scientific Literacy and Physics Problem Solving Skills through Inquiry-Based Learning for STEM Education. Journal of Physics: Conference Series, 1108(1). https://doi.org/10.1088/1742-6596/1108/1/012026 